\title{
Hemichorea-hemiballism associated with hyperglycemia and a developmental venous anomaly
}

Figure Neuroimaging
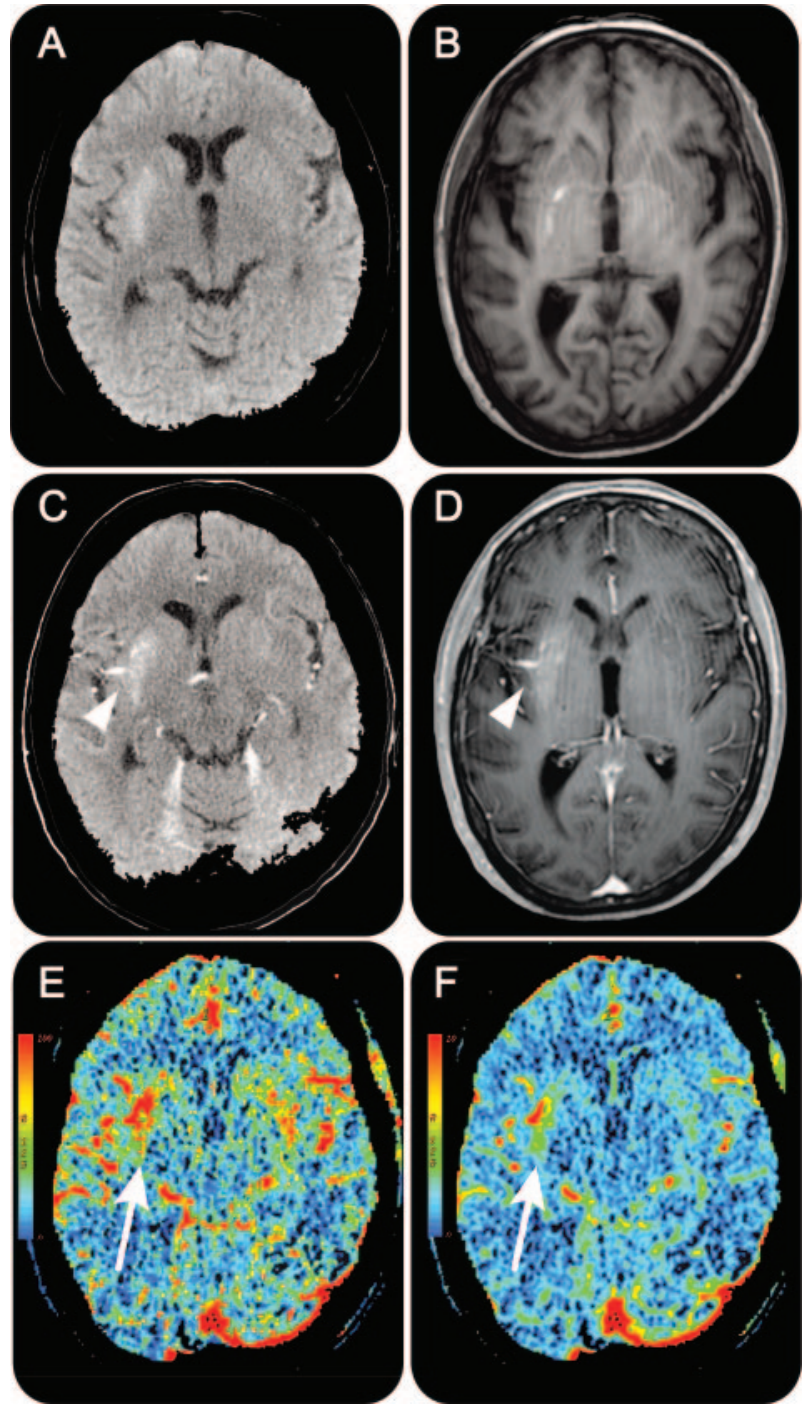

The right putamen is hyperdense on CT head (A) and hyperintense on T1-weighted MRI brain (B) which is classic for hyperglycemia-induced hemichorea-hemiballism. The characteristic caput medusa of a developmental venous anomaly (arrowheads) is seen on CT head with contrast (C) and gadolinium-enhanced 3T MRI brain (D). CT perfusion demonstrates increased cerebral blood flow (E) and increased cerebral blood volume (F) in the affected putamen (arrows).

A 70-year-old woman presented with a 3-week history of progressive left hemichorea-hemiballism. Based on elevated serum glucose $(384 \mathrm{mg} / \mathrm{dL}$ ) and HbA1c $(13.2 \%)$ plus neuroimaging findings (figure, A and B), she was diagnosed with hyperglycemia-induced hemichorea-hemiballism. ${ }^{1}$ She was treated with insulin and risperidone with near resolution after 4 days. Additional neuroimaging (figure, $\mathrm{C}$ and D) revealed a developmental venous anomaly (DVA) adjacent to the affected putamen. The DVA was associated with increased cerebral blood flow and volume (figure, E and F). DVAs are typically asymptomatic. However, we propose 
that altered hemodynamics within the basal ganglia together with this patient's metabolic disturbance resulted in the movement disorder: a 2-hit hypothesis.

L.V. Kalia, MD, PhD, L. Mozessohn, MD, R.I. Aviv, MD, L. da Costa, MD, A.E. Lang, MD, S. Shadowitz, MDCM, MSc, M. Masellis, MD, MSc, Toronto, Canada

Author contributions: Dr. Kalia conceived and designed the study, analyzed and interpreted the data, and drafted and revised the manuscript. Dr. Mozessohn contributed to design of the study and to revision of the manuscript. Dr. Aviv contributed to analysis and interpretation of the data and to revision of the manuscript. Dr. Da Costa contributed to revision of the manuscript. Dr. Lang contributed to design of the study and to revision of the manuscript. Dr. Shadowitz contributed to design of the study and to revision of the manuscript. Dr. Masellis conceived and designed the study, analyzed and interpreted the data, and drafted and revised the manuscript.

Acknowledgment: The authors thank the patient for contributing her time to this case study.

Study funding: L.V.K. is supported by a Canadian Health Institutes of Research (CIHR) Clinician-Scientist Award. M.M. receives operating funds from a Parkinson Society Canada New Investigator Award and is funded by the Department of Medicine, Sunnybrook Health Sciences Centre.

Disclosure: Dr. Kalia is funded by a Clinician-Scientist Phase I Award from the CIHR. Dr. Mozessohn, Dr. Aviv, and Dr. Da Costa report no disclosures. Dr. Lang has served on scientific advisory boards for Abbott, Allon Therapeutics, Inc., Biovail Corporation, Boehringer Ingelheim, Cephalon, Inc., Ceregene, Eisai Inc., Medtronic, Inc., Lundbeck Inc., NeuroMolecular Pharmaceuticals, Novartis, Merck Serono, Solvay Pharmaceuticals, Inc., TaroPharma, and Teva Pharmaceutical Industries Ltd.; has received speaker honoraria from GlaxoSmithKline and UCB; receives/has received research support from the CIHR, the Dystonia Medical Research Foundation, the Michael J. Fox Foundation, the National Parkinson Foundation, and the Ontario Problem Gambling Research Centre; and has served as an expert witness in cases related to the welding industry. Dr. Shadowitz reports no disclosures. Dr. Masellis serves as CME lecturer for and has received speaker honoraria from Novartis and EMD Serono, Inc.; serves as an Associate Editor for Current Pharmacogenomics and Personalized Medicine; has received publishing royalties from Henry Stewart Talks; serves as a consultant for Bioscape Medical Imaging CRO; and receives research support from Novartis, a CIHR Clinician Scientist Award, the Department of Medicine, Sunnybrook Health Sciences Centre, a Parkinson Society Canada New Investigator Award.

Correspondence \& reprint requests to Dr. Kalia: lorraine.kalia@utoronto.ca

1. Postuma RB, Lang AE. Hemiballism: revisiting a classic disorder. Lancet Neurol 2003;2:661-668.

2. Hanson EH, Roach CJ, Ringdahl EN, et al. Developmental venous anomalies: appearance on whole-brain CT digital subtraction angiography and CT perfusion. Neuroradiology 2011;53:331-341.

\section{NeuroImages Are Free at www.neurology.org!}

All Neurology ${ }^{\circledR}$ NeuroImages can now be freely accessed on the Neurology Web site. See them at www.neurology.org, where you can also sign up for journal email alerts and check out other online features, including the Resident \& Fellow section, Neurology: Clinical Practice, and the weekly Neurology Podcasts. 


\section{Neurology}

\section{Hemichorea-hemiballism associated with hyperglycemia and a developmental venous anomaly}

L.V. Kalia, L. Mozessohn, R.I. Aviv, et al.

Neurology 2012;78;838

DOI 10.1212/WNL.0b013e318249f733

\section{This information is current as of March 12, 2012}

\section{Updated Information \& Services}

References

Citations

Subspecialty Collections

Permissions \& Licensing

Reprints including high resolution figures, can be found at: http://n.neurology.org/content/78/11/838.full

This article cites 2 articles, 0 of which you can access for free at: http://n.neurology.org/content/78/11/838.full\#ref-list-1

This article has been cited by 2 HighWire-hosted articles: http://n.neurology.org/content/78/11/838.full\#\#otherarticles

This article, along with others on similar topics, appears in the following collection(s):

Basal ganglia

http://n.neurology.org/cgi/collection/basal_ganglia

\section{Chorea}

http://n.neurology.org/cgi/collection/chorea

CT

http://n.neurology.org/cgi/collection/ct

Endocrine

http://n.neurology.org/cgi/collection/endocrine

Information about reproducing this article in parts (figures,tables) or in its entirety can be found online at:

http://www.neurology.org/about/about_the_journal\#permissions

Information about ordering reprints can be found online:

http://n.neurology.org/subscribers/advertise

Neurology ${ }^{\circledR}$ is the official journal of the American Academy of Neurology. Published continuously since 1951, it is now a weekly with 48 issues per year. Copyright Copyright (? 2012 by AAN Enterprises, Inc.. All rights reserved. Print ISSN: 0028-3878. Online ISSN: 1526-632X.

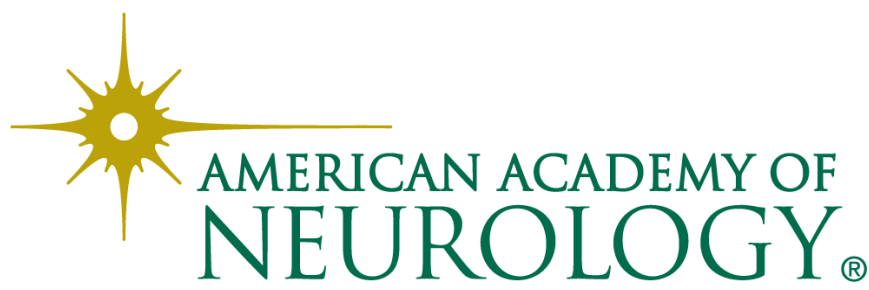

